\title{
The Management of Wilms Tumor in West Africa: A Case Series Report from the Military Teaching Hospital of Cotonou
}

Sossa Jean ${ }^{1 *}$, Avakoudjo Dedjinnin Josue Georges ${ }^{2}$, Yevi Dodji Magloire Ines ${ }^{2}$, Fanou Lionelle ${ }^{1}$, Natchagande Gilles ${ }^{2}$, Agounkpe Michel Michael ${ }^{2}$, Hodonou Fred ${ }^{2}$, Hounto Yao Felicien ${ }^{1}$, Atadokpede Felix $^{1}$

${ }^{1}$ Service d'Urologie, HIA-CHU, Cotonou
${ }^{2}$ Clinique Universitaire d'Urologie-Andrologie, CNHU-HKM, Cotonou

DOI: $10.36347 /$ sasjs.2021.v07i02.019

| Received: 10.02.2021 | Accepted: 23.02.2021 | Published: 25.02.2021

*Corresponding author: Sossa Jean

We report the results of our first management of a tiny cohort of 4 cases of Wilm's tumor. The patients were 1 male aged 4.2 years and 3 females aged 3.3, 5.6 and 9.5 years. The mean age was 5.7 years. We performed an up-front nephrectomy in 3 patients. Surgery was not feasible in the 5.6 years old female who got lost to follow-up. Although adjuvant chemotherapy was indicated in all of the 3 operated patients, only the male patient could afford it. One female patient experienced pulmonary and brain metastases 16 months after surgery and died 42 months after surgery. On last follow-up, 2 patients in 3 (67\%), 1 male and 1 female, were still surviving and disease-free at respectively 72 and 69 months, i.e. nearly 6 years after surgery.

Keywords: Wilm's tumor - nephrectomy - chemotherapy - survival.

Copyright $\odot 2021$ The Author(s): This is an open-access article distributed under the terms of the Creative Commons Attribution 4.0 International License (CC BY-NC 4.0) which permits unrestricted use, distribution, and reproduction in any medium for non-commercial use provided the original author and source are credited.

\section{INTRODUCTION}

The Wilm's tumor (WT) also called nephroblastoma is rare but it is the most frequent renal tumor in the children [1]. Its treatment combines radical nephrectomy, chemotherapy and radiation therapy. The tumor is known in Benin: 16 cases were counted among 214 cases of various children's urological pathologies collected in 10 years at the National Teaching Hospital of Cotonou [2]. We aim to evaluate the outcome of WT's management in the Military Teaching Hospital of Cotonou.

\section{MATERIAL AND METHOD}

WT-affected children underwent upfront nephrectomy through a sub-costal abdominal incision followed by adjuvant chemotherapy based on pathology. Radiation therapy is not yet available in our country.

\section{RESULTS}

Four cases of WT were diagnosed and managed in our facility. The patients' demographic characteristics and their tumors' features are summarized on table 1 . Images 1 and 2 respectively show the patient a tumor on CT scan and the surgically removed tumor from patient $\mathrm{B}$. The patient $\mathrm{B}$ was male and the three others were females. The patient $\mathrm{A}$ had a tri-phasic tumor, the patient $\mathrm{B}$ had a bi-phasic tumor and the patient $\mathrm{D}$ had a mono-phasic tumor. No nephrogenic rest was detected in anyone of the three operated tumors. In the patient $\mathrm{B}$, the tumor was ruptured at its lower pole with two nodules on the right flank abdominal wall but the peritoneum and the intraperitoneal viscera were not invaded. In the patient $\mathrm{C}$, the tumor could not be resected: we closed the right subcostal wound, opting for neo-adjuvant chemotherapy but we lost her to follow-up. We indicated adjuvant chemotherapy in each one of the three operated patients but only the patient B could afford it. The follow-up data of the three operated patients are available on table 2. After 72 and 69 months respectively, the patient B and $\mathrm{D}$ developed no metastasis and no local recurrence. In contrast, the patient $\mathrm{A}$ developed, 16 months after nephrectomy, a pulmonary metastasis (right lower lobe) and two brain metastases. She died in the $42^{\text {nd }}$ postsurgical month. 
Sossa Jean et al., SAS J Surg, Feb, 2021; 7(2): 102-106

Table-1: Demographic characteristics of the patients and histologic characteristics of the tumors

\begin{tabular}{|c|c|c|c|c|}
\hline Patients & Patient A & Patient B & Patient C & Patient D \\
\hline Age $($ mean $=5.63$ years $)$ & 3.25 & 4.17 & 5.58 & 9.5 \\
\hline Sex $($ sex ratio $=1 / 4)$ & $\mathrm{F}^{*}$ & $M^{*}$ & $\mathrm{~F}$ & $\mathrm{~F}$ \\
\hline Symptoms & $\mathrm{AM}^{* *}$ & AM, pain & AM, Dyspnea & AM \\
\hline Affected kidney & $\mathrm{L}^{*}$ & $\mathrm{R}^{*}$ & $\mathrm{R}$ & $\mathrm{L}$ \\
\hline Mass weight (grams) & & 1200 & & 1399 \\
\hline Tumor diameter $(\mathrm{cm})$ & 12 & 19 & & 16 \\
\hline \multicolumn{5}{|l|}{ Tumor histology } \\
\hline Blastema (\%) & 35 & 90 & & 0 \\
\hline Epithelium (\%) & 64 & 10 & & 100 \\
\hline Stroma $(\%)$ & 1 & 0 & & 0 \\
\hline Anaplasia (\%) & 0 & 0 & & 0 \\
\hline Capsule rupture & No & Yes & & No \\
\hline Nephrogenic rest & 0 & 0 & & 0 \\
\hline Necrosis (\%) & 33 & 20 & & \\
\hline Presence of vascular emboli & Yes & No & & No \\
\hline COG stage & I FH* & III FH & & I FH \\
\hline
\end{tabular}

Table-2: Patients post-nephrectomy management and follow-up data

\begin{tabular}{|l|c|c|c|}
\hline Patients & PATIENT A & PATIENT B & PATIENT D \\
\hline Adjuvant Chemotherapy & & & \\
\hline Drugs & - & AVD* & - \\
\hline Duration (weeks) & - & 26 & - \\
\hline Follow-up & & & 69 \\
\hline Follow-up Duration (months) & 76 & 72 & - \\
\hline Metastasis (site) & Lung \& Brain & - & 69 \\
\hline Metastasis-free survival (months) & 16 & 72 & - \\
\hline Time from Surgery to Death (months) & 42 & - & \\
\hline$* A V D=$ Dactinomycin/Vincristin/Doxorubicin \\
\hline
\end{tabular}

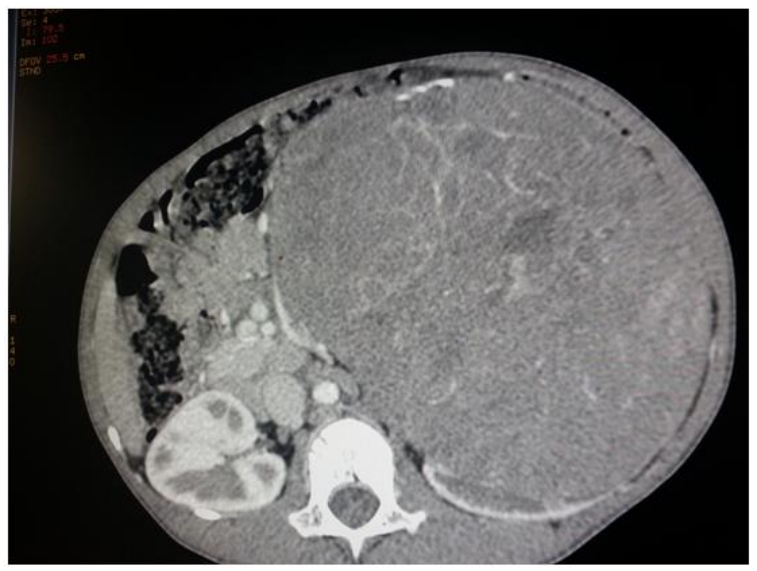

Image-1: CT scan showing a left kidney tumor patient $\mathbf{A}$

\section{DISCUSSION}

We used upfront nephrectomy in order to bypass poverty which mainly alters access to therapy in our patients. There are two major ways to manage WT in the world. The SIOP (International Society of Pediatric Oncology) advocates pre-nephrectomy chemotherapy in patients aged 6 months or more whereas the COG/NWTSG (Children's Oncology Group/National Wilms Tumor Study Group) advocates up-front nephrectomy followed by chemotherapy based

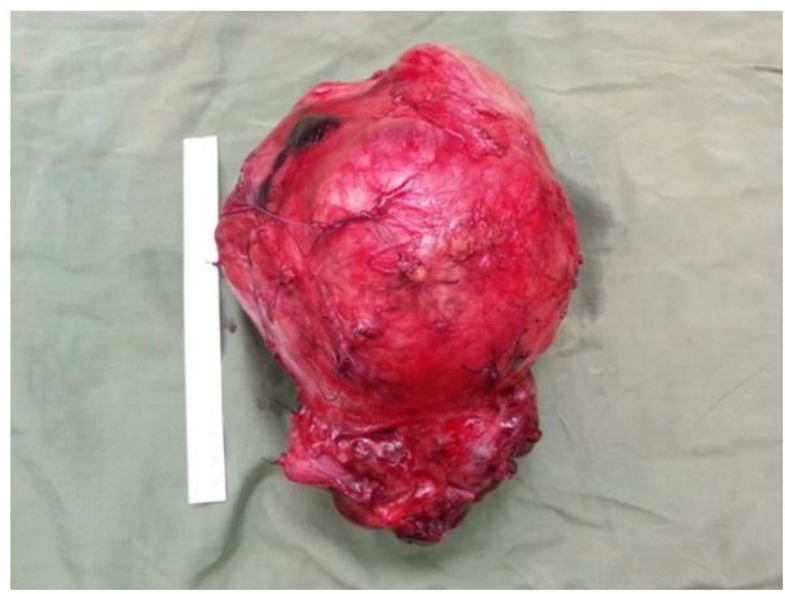

Image-2: the right kidney tumor from patient $B$

on pathology. Both ways lead to similar outcomes: the survival rate is beyond $90 \%$ for localized WTs and more than $70 \%$ for metastatic WTs [3].

Patients A and D had benefited from surgery alone as they could not afford chemotherapy. Nephrectomy alone can achieve up to an $86.5 \% 2$ years disease-free survival rate in children with less than $550 \mathrm{~g}$ stage I favorable histology tumor [4-7]. But the case C shows that surgery is not always feasible in every 
patient. Contra-indications to upfront nephrectomy are: tumor thrombus above hepatic veins, gross involvement of contiguous structures other than the adrenal gland, bilateral WT, extensive pulmonary compression from a massive tumor, metastases, risk of incomplete resection $[8,9]$.

The patients' age ranges from 3.25 to 9.5 years. In the United States, WT's incidence peaks between 2 and 3 years of age [10]. Only one in the four patients is male. The sex ratio in WT affected patients vary through race and ethnic groups [11, 12]. Nevertheless, the small size of the cohort does not allow a full and precise demographic comparison.

All four patients exhibit abdominal mass. Common symptoms of WT are abdominal mass and hematuria [13]. All four patients developed a unilateral tumor and no metachronous or contralateral tumor until their last follow-up exam. But bilateral or metachronous contralateral WTs may exist in some children [14-18]. Authors use nephron sparing surgery to avoid renal failure in patients with bilateral WT [19, 20].

Two in three patients remained alive and disease-free nearly 6years after surgery. That survival rate is lower than the one achieved in western countries [21] and lower than the $72 \%$ overall survival rate achieved by the Second French African Pediatric Oncology Group in sub-Saharan Africa [22]. Poverty is a major contributor to that situation. In fact, the patient $B$ had the worst disease but obviously adjuvant chemotherapy helped him to survive much longer. For example, The Collaborative Wilms Tumor Africa Project has implemented an adapted treatment guideline to address the adverse impact of poverty on WT treatment outcome in Sub-Saharan Africa [23]. The patient $\mathrm{B}$ has developed a post-chemotherapy complication so far. Nevertheless, WT survivors may develop second malignancies (sarcoma, leukemia), a cardiac dysfunction, lung toxicity or musculoskeletal and soft tissue defects as adverse effects of chemotherapy or radiation therapy [24-26].

No nephrogenic rest was detected in any one of the 3 operated children. Nephrogenic rest is present in $40 \%$ of nephroblastomas and $90 \%$ of bilateral cases of nephroblastoma [27, 28]. Persistent blastema or nephrogenic rest is the precursor of Wilms tumor [29]. In fact, the development of the kidney involves the ureteric bud and the metanephric mesenchyme and blastema. The blastema, which generates the glomeruli and the renal tubules, disappears at 36 weeks of gestation. But it may persist in $1 \%$ of infants as a nephrogenic rest [27]. The presence of diffuse or multifocal nephrogenic rest is associated with a higher risk of bilateral WTs [27, 28].

A Wilms tumor may be a blastema, an epithelium, a stroma or it may be a mixture of variable proportions of those histologic types. Whatever the components of a nephroblastoma, anaplasia may be present and represents the COG unfavorable histology.

Interestingly, both the patients A and D had a COG favorable stage I disease, both of them received no adjuvant chemotherapy but they showed opposite follow-up profiles. The only known differences between the patients $\mathrm{A}$ and $\mathrm{D}$ were age and tumor size. Is it a clue that the tumor weight to patient weight ratio could be a prognostic factor? We don't know.

Nevertheless, a 550grams cut-off in tumor weight can reliably discriminate poor prognosis diseases from better prognosis ones [4-7]. Other genetic factors might have triggered the prognostic discrepancy between patients $A$ and $D$ as the literature shows that $1 \mathrm{q}$ gain [30-33] or loss of heterogenicity in 1p and 16q [34] are associated with metastasis and death in COG favorable disease.

\section{CONCLUSION}

We achieved a 2 in 3 overall survival rate at 6 years in treating 3 of 4 cases of Wilm's tumor. Early and more affordable access to clinical care can better that result.

\section{REFERENCES}

1. Pastore G, Znaor A, Spreafico F, Graf N, PritchardJones K, SteliarovaFoucher E. "Malignant renal tumours' incidence and survival in European children (1978-1997): report from the Automated Childhood Cancer Information System project," European Journal of Cancer. 2006; 42(13): 21032114.

2. Agossou-Voyeme AK, Fiogbe MA, Goundete J, Hounnou GM, Hodonou R. Paedriatric urologic pathologies at the National Teaching Hospital in Cotonou: a etiological and therapeutic aspects. African Journal of Paediatric Surgery. 2013; 10(2): 135-139.

3. Jeffrey SD, Norbert G, James IG, Conrad VF, Elizabeth AM, Filippo S, Marry Van den H-E, Kathy P-J. Advances in Wilms Tumor Treatment and Biology: Progress through International Collaboration. J Clinical Oncol. 2015; 33(27): 2999-3007

4. Fernandez CV, Perlman EJ, Mullen EA, Chi YY, Hamilton TE, Gow KW. Clinical Outcome and Biological Predictors of Relapse after Nephrectomy Only for Very Low-risk Wilms Tumor: A Report From Children's Oncology Group AREN0532. Annals of surgery. 2017; 265(4):835-40

5. Shamberger RC, Anderson JR, Breslow NE, Perlman EJ, Beckwith JB, Ritchey ML. Long-term outcomes for infants with very low risk Wilms tumor treated with surgery alone in National Wilms Tumor Study-5. Annals of surgery. 2010; 251(3):555-8. 
6. Green DM, Breslow NE, Beckwith JB, Ritchey ML, Shamberger RC, Haase GM. Treatment with nephrectomy only for small, stage I/favorable histology Wilms' tumor: a report from the National Wilms' Tumor Study Group. J Clin Oncol. 2001; 19(17):3719-24.

7. Green DM, Breslow NE, Beckwith JB, Takashima J, Kelalis P, D'Angio GJ. Treatment outcomes in patients less than 2 years of age with small, stage I, favorable-histology Wilms' tumors: a report from the National Wilms' Tumor Study. J Clin Oncol. 1993; 11(1):91-5.

8. Kieran K, Ehrlich PF. Current surgical standards of care in Wilms tumor. Urol Oncol. 2016; 34(1): 1323.

9. Gleason JM, Lorenzo AJ, Bowlin PR, Koyle MA. Innovations in the management of Wilms' tumor. Therapeutic advances in urology. 2014 Aug;6(4):165-76.

10. Dénes FT, Duarte RJ, Cristófani LM, Lopes RI. Pediatric genitourinary oncology. Frontiers in pediatrics. 2013 Dec 16;1:48.

11. Chu A, Heck JE, Ribeiro KB, Brennan P, Boffetta P, Buffler P, Hung RJ. Wilms' tumour: a systematic review of risk factors and meta- analysis. Paediatric and perinatal epidemiology. 2010 Sep;24(5):449-69.

12. Fukuzawa R, Breslow NE, Morison IM, Dwyer P, Kusafuka T, Kobayashi Y, Becroft DM, Beckwith JB, Perlman EJ, Reeve AE. Epigenetic differences between Wilms' tumours in white and east-Asian children. The Lancet. 2004 Feb 7;363(9407):44651.

13. Kaste SC, Dome JS, Babyn PS, Graf NM, Grundy P, Godzinski J, Levitt GA, Jenkinson H. Wilms tumour: prognostic factors, staging, therapy and late effects. Pediatric radiology. 2008 Jan;38(1):217.

14. Davidoff AM, Giel DW, Jones DP, Jenkins JJ, Krasin MJ, Hoffer FA, Williams MA, Dome JS. The feasibility and outcome of nephron- sparing surgery for children with bilateral Wilms tumor: The St. Jude Children's Research Hospital experience: 1999-2006. Cancer. 2008 May 1;112(9):2060-70.

15. COOPER CS, JAFFE WI, HUFF DS, CANNING DA, ZDERIC SA, MEADOWS AT, D'ANGIO GJ, SNYDER HM. The role of renal salvage procedures for bilateral Wilms tumor: a 15-year review. The Journal of urology. 2000 Jan;163(1):265-8.

16. Paya K, Horcher E, Lawrenz K, Rebhandl W, Zoubek A. Bilateral Wilms' tumor-surgical aspects. European journal of pediatric surgery. 2001 Apr;11(02):99-104.

17. Charlton J, Irtan S, Bergeron C, Pritchard-Jones K. Bilateral Wilms tumour: a review of clinical and molecular features. Expert reviews in molecular medicine. 2017;19.
18. Wang HH, Abern MR, Cost NG, Chu DI, Ross SS, Wiener JS, Routh JC. Use of nephron sparing surgery and impact on survival in children with Wilms tumor: a SEER analysis. The Journal of urology. 2014 Oct;192(4):1196-202.

19. Fuchs J, Szavay P, Seitz G, Handgretinger R, Schäfer JF, Warmann SW. Nephron sparing surgery for synchronous bilateral nephroblastoma involving the renal hilus. The Journal of urology. 2011 Oct 1;186(4):1430-6.

20. Davidoff AM. Wilms' tumor. Current Opinion in Pediatrics. 2009; 21(3): 357-364.

21. Yao AJJ, Moreira C, Fousseni T, Kaboret S, Pondy A, Narison MLR, Guedenon K, Mallon B, Patte C. Treatment of Wilms Tumor in Sub-Saharan Africs: Results of the Second French African Pediatric Oncology Group Study. Journal of Global Oncology. 2019; 5:1-8.

22. Israels $\mathrm{T}$, Painstil $\mathrm{V}$, Nyirenda $\mathrm{D}$. Improved outcome at end of treatment in the collaborative Wilms tumor Africa project. Pediatric Blood Cancer. 2018; 65(5): e26945.

23. Johnston DL, Bishop MW, Hudson MM. Subsequent Neoplasms in Adult Survivors of Childhood Genitourinary Tumors. Urology. 2015; 86(4): 666-75.

24. Termuhlen AM, Tersak JM, Liu Q. Twenty-five year follow-up of childhood Wilms tumor: a report from the Childhood Cancer Survivor Study. Pediatr Blood Cancer. 2011; 57(7): 1210-6.

25. Green DM, Donckerwolcke R, Evans AE. Late effects of treatment for Wilms tumor. Hematol Oncol Clin North Am. 1995; 9:1317-1327.

26. Beckwith JB, Kiviat NB, Bonadio JF. Nephrogenic rests, nephroblastomatosis, and the pathogenesis of Wilms' tumor. Pediatric pathology. 1990 Jan 1;10(1-2):1-36.

27. Breslow NE, Beckwith JB, Perlman EJ, Reeve AE. Age distributions, birth weights, nephrogenic rests, and heterogeneity in the pathogenesis of Wilms tumor. Pediatric blood \& cancer. 2006 Sep;47(3):260-7.

28. Beckwith JB. Nephrogenic rests and the pathogenesis of Wilms tumor: developmental and clinical considerations. American journal of medical genetics. 1998 Oct 2;79(4):268-73.

29. Gratias EJ, Dome JS, Jennings LJ, Chi YY, Tian J, Anderson J, Grundy P, Mullen EA, Geller JI, Fernandez CV, Perlman EJ. Association of chromosome 1q gain with inferior survival in favorable-histology Wilms tumor: A report from the Children's Oncology Group. Journal of Clinical Oncology. 2016 Sep 10;34(26):3189.

30. Chagtai T, Zill C, Dainese L, Wegert J, Savola S, Popov S, Mifsud W, Vujanić G, Sebire N, Le Bouc $\mathrm{Y}$, Ambros PF. Gain of $1 \mathrm{q}$ as a prognostic biomarker in Wilms tumors (WTs) treated with preoperative chemotherapy in the International Society of Paediatric Oncology (SIOP) WT 2001 trial: a SIOP renal tumours biology consortium 
study. Journal of Clinical Oncology. 2016 Sep 10;34(26):3195.

31. Gratias EJ, Jennings LJ, Anderson JR, Dome JS, Grundy P, Perlman EJ. Gain of $1 \mathrm{q}$ is associated with inferior event- free and overall survival in patients with favorable histology Wilms tumor: A report from the Children's Oncology Group. Cancer. 2013 Nov 1;119(21):3887-94.

32. Segers H, van den Heuvel- Eibrink MM, Williams $\mathrm{RD}$, van Tinteren $\mathrm{H}$, Vujanic $\mathrm{G}$, Pieters $\mathrm{R}$, Pritchard- Jones K, Bown N, Children's Cancer and Leukaemia Group and the UK Cancer Cytogenetics Group. Gain of 1q is a marker of poor prognosis in Wilms' tumors. Genes, Chromosomes and Cancer. 2013 Nov;52(11):1065-74.
33. Hing S, Lu YJ, Summersgill B, King-Underwood L, Nicholson J, Grundy P, Grundy R, Gessler M, Shipley J, Pritchard-Jones K. Gain of $1 \mathrm{q}$ is associated with adverse outcome in favorable histology Wilms' tumors. The American journal of pathology. 2001 Feb 1;158(2):393-8.

34. Grundy PE, Breslow NE, Li S, Penman E, Beckwith JB, Ritchey ML, Shamberger RC, Haase GM, D'Angio GJ, Donaldson M, Coppes MJ. Loss of heterozygosity for chromosomes $1 p$ and $16 q$ is an adverse prognostic factor in favorable-histology Wilms tumor: a report from the National Wilms Tumor Study Group. Journal of clinical oncology. 2005 Dec 1;23(29):7312-21. 